\title{
Tuberculosis and/or HIV Infection and Associated Socio-Behavioural Factors in Immigrants, in Portugal: A Cross-Sectional, Community-Based Descriptive Study
}

\author{
Rhaisa Farias $^{a}$ Isabel Couto $^{b}$ Marta Pingarilho $^{b}$ Inês Fronteira ${ }^{b}$ \\ ${ }^{a}$ M.Sc. Biomedical Sciences, Instituto de Higiene e Medicina Tropical, Lisbon, Portugal; b Global Health and Tropical \\ Medicine, GHTM, Instituto de Higiene e Medicina Tropical, IHMT, Universidade Nova de Lisboa, UNL, Lisbon, \\ Portugal
}

\section{Keywords}

Immigrants · Tuberculosis · HIV-AIDS · HIV-tuberculosis co-infection · Epidemiology

\begin{abstract}
Introduction: Portugal is one of the countries in Western Europe with the highest prevalence of tuberculosis (TB) and human immunodeficiency virus (HIV). The prevalence among migrants is estimated to be higher than among nonmigrants, which suggests a greater vulnerability of this population. Aim: To describe the distribution of TB, HIV and HIVTB co-infection and socio-behavioural factors associated with immigrants that lived in the metropolitan area of Lisbon and used the services of a Non-Governmental Organization (NGO). Methods: Quantitative, cross-sectional and descriptive pilot study. An anonymous and structured questionnaire developed specifically for the study was applied by NGO employees duly trained for this purpose to a purposeful sample of 100 immigrants attending health services in an NGO in the metropolitan area of Lisbon, Portugal. Results: The prevalence of HIV-TB extrapulmonary coinfection and HIV infection was $1 \%(n=1)$ and $17 \%(n=17)$, respectively.
\end{abstract}

Only 1 immigrant had 4 out of the 5 symptoms suggestive of TB. No cases of pulmonary TB were identified, although 3 of the immigrants reported having been treated for pulmonary TB in the past. The participants were young, mainly female and some were male-to-female transsexuals. Most were from the community of Portuguese-speaking countries, especially from Brazil, and almost half of them had not regularized their immigration status. Additionally, almost one-fifth of immigrants were unemployed (17\%), and one-sixth performed sex work (14\%). Most of the participants (71\%) sometimes used or never used a condom during sexual intercourse. Additionally, 40\% revealed using illicit drugs and $1 \%$ said that they had shared injection material in the last 12 months. Discussion: Being non-employed, with a low income and a lower level of education, consumption of illicit drugs and regular tobacco consumption were common characteristics in the immigrants studied, which points out social and economic disadvantages that could influence the risk of acquiring HIV and TB. Policies on latent TB infection and TB diagnosis are urgently needed, mainly aimed at vulnerable groups and culturally diverse populations.

(c) 2022 The Author(s). Published by S. Karger AG, Basel on behalf of NOVA National School of Public Health (c) 2022 The Author(s). Published by S. Karger AG, Basel on behalf of NOVA National School of Public Health

This is an Open Access article licensed under the Creative Commons Attribution-NonCommercial-4.0 International License (CC BY-NC) (http://www.karger.com/Services/OpenAccessLicense), applicable to the online version of the article only. Usage and distribution for commercial purposes requires written permission.
Correspondence to:

Inês Fronteira, ifronteira@ihmt.unl.pt 


\section{Tuberculose e/ou infeção pelo VIH e fatores sociocomportamentais associados em imigrantes, em Portugal: um estudo transversal descritivo de base comunitária}

\section{Palavras Chave}

Imigrantes · Tuberculose · VIH-SIDA · Coinfecção VIHtuberculose $\cdot$ Epidemiologia

\section{Resumo}

Introdução: Portugal é um dos países da Europa Ocidental com a maior prevalência de Tuberculose (TB) e Vírus da Imunodeficiência Humana (VIH). Estima-se que a prevalência entre os migrantes seja mais elevada do que entre os não migrantes, o que sugere uma maior vulnerabilidade desta população. Objetivo: Descrever a distribuição da tuberculose, do VIH e dos fatores sócio-comportamentais associados em imigrantes da área metropolitana de Lisboa que usavam os serviços de uma ONG. Métodos: Estudo piloto quantitativo, transversal e descritivo. Foi aplicado um questionário anónimo e estruturado desenvolvido especificamente para o estudo, por funcionários de uma ONG da área metropolitana de Lisboa, Portugal, devidamente formados para o efeito, a uma amostra intencional de 100 imigrantes. Resultados: A prevalência de coinfecção extrapulmonar por HIV-TB e infeção por HIV foi de $1,0 \%(n=1)$ e $17,0 \%(n=17)$, respetivamente. Apenas $1 \%$ dos imigrantes apresentavam todos os sintomas sugestivos de tuberculose. Não foram identificados casos de tuberculose pulmonar, embora três dos imigrantes tenham sido tratados para a tuberculose pulmonar no passado. Os imigrantes eram jovens, principalmente do sexo feminino e alguns eram transexuais do sexo masculino para o sexo feminino. A maioria era oriunda da Comunidade de Países de Língua Portuguesa, principalmente do Brasil, e quase metade não havia regularizado a situação migratória. Além disso, quase um quinto estava desempregado (17\%), e um sexto realizava trabalho sexual (14\%). A maioria dos participantes (71\%) nunca ou às vezes usava preservativo nas relações sexuais; somado ao fato de $40,0 \%$ revelarem uso de drogas ilícitas e $1 \%$ ter relatado ter compartilhado material injetável nos últimos doze meses. Conclusão: Estar desempregado, ter baixos rendimentos e baixo nível de educação, consumir drogas ilícitas e consumir regularmente tabaco foram características comuns nos imigrantes estudados que apontam para desvantagens sociais e económicas que podem influenciar o risco de VIH e TB. Por conse- guinte, são urgentemente necessárias políticas de rastreio de tuberculose latente e diagnóstico de tuberculose, destinadas principalmente a grupos vulneráveis e populações culturalmente diversas.

(c) 2022 The Author(s). Published by S. Karger AG, Basel on behalf of NOVA National School of Public Health

\section{Background}

Tuberculosis (TB) along with human immunodeficiency virus (HIV) infection is responsible for the largest burden of disease on global health. The increase in the global number of cases of TB is linked to HIV infection, one of the most well-known risk factors for the development of active TB, both by reactivating latent Mycobacterium tuberculosis infection and by reinfection [1]. Globally, people living with HIV are 20-40 times more likely to develop active TB disease than people without HIV [2]. The synergy between TB and HIV accelerates the deterioration of immune functions and results in higher rates of morbidity and mortality [3].

On the one hand, TB is an opportunistic infection that causes exacerbation of viral load and decreased CD4 lymphocyte count in HIV-positive individuals. On the other hand, HIV increases the risk of TB progression and can alter its pathogenesis, leading to a negative bacilloscopy result, atypical chest radiography and extrapulmonary manifestations - thus being able to escape routine diagnostic procedures. Accordingly, the association between TB and HIV presents significant challenges in the treatment of co-infected patients, including the repressive effect on the immune system, drug interactions and cumulative toxicities of overlapping drugs, further complicated by the development of multi-drug-resistant TB $[4,5]$.

The epidemiology of TB is reflected in the socio-economic determinants of health, such as social, political and economic conditions in which people are born, live, work and age. While much of the burden of HIV-TB co-infection is concentrated in countries with limited resources (where the TB burden associated with HIV is higher), globalization and migration are important factors in the global spread of HIV-TB co-infection [2, 3]. Studies show that migrant populations are at greater risk of acquiring HIV and/or TB than the general population, which suggests that these populations are more vulnerable $[3,5,6]$.

The obstacles faced by immigrants may already be present in the country of origin, through previous contacts with infectious agents (pre-migration phase), during the travel (migratory phase) and due to the living con- 
ditions in the destination country (post-migratory phase) [7]. The adversities faced in the destination country, such as limited socio-economic resources, dwellings in degraded and unhealthy environments, precarious working conditions, malnutrition, withdrawal from family relationships, use of drugs and difficulties in accessing healthcare - especially for immigrants with irregular status enhance the exposure to infectious diseases, such as TB and HIV $[2,6]$.

In the WHO European Region, studies report significantly higher prevalence rates of HIV-TB co-infection among migrants compared to nationals [3]. Portugal is one of the European countries with the highest prevalence of TB with a notification rate of 18.0 cases per 100,000 inhabitants in 2019, $25 \%$ of which occurred in immigrants and with Lisbon's and Porto's districts registering the highest notification rates (26.5 and 25.7 per 100,000 inhabitants, respectively) [8]. Previous studies in Portugal reported a higher risk for TB infection within areas of greater density of migrants, a high prevalence of HIV/AIDS and poor living conditions $[9,10]$.

This study aimed to describe the distribution of TB, HIV and HIV-TB co-infection and socio-behavioural factors associated with immigrants that lived in the metropolitan area of Lisbon and used the services of a NonGovernmental Organization (NGO) providing care to this population.

\section{Methods}

\section{Study Design and Participants}

From February through June 2019, we conducted a cross-sectional, quantitative and descriptive study as part of a larger research project that aimed at piloting a community-based TB syndromic screening method in immigrants attending an NGO in Lisbon Greater Area, one of the areas in Portugal with the highest concentration of immigrants. This NGO has been working since the beginning of the 2000s and currently has several projects addressing sexually transmitted diseases and TB in vulnerable populations, including migrants.

A purposeful sampling with sequential inclusion of all eligible participants presenting at the NGO between February 22 and June 26 in 2019 was used until a total of 100 immigrants were included. The size of the sample was determined by the available budget for sputum collection and culture and time to conduct the study agreed with the funder. Inclusion criteria for this study were: (1) being an immigrant (with non-Portuguese nationality or dual nationality); (2) being over 18 years of age; and (3) being a user of the NGO services.

\section{Data Collection}

Data collection comprised 3 phases: (1) anonymous close-ended questionnaire on sociodemographic characteristics and atti- tudes and practices regarding HIV and TB; (2) HIV rapid test, including pre- and post-test counselling; and (3) sputum sample collection. The participants were given the option of only answering the questionnaire, not taking the HIV test or sputum test, or performing either the test or sputum collection without answering the questionnaire.

Data were collected in appropriate spaces, providing privacy and comfort to the participants. The questionnaire was applied by the NGO staff specially trained for this study. After answering the questionnaire, the participants who were unaware of their HIV status or who had previously tested HIV negative were asked to take the rapid HIV test. The HIV rapid test was performed following the guidelines of the NGO that already provided this service to its users.

A sample of sputum was requested from participants who presented at least 4 of the 5 symptoms suggestive of TB (fever, weight loss, night sweats, coughing for more than 3 weeks and severe tiredness).

The data collected included age, gender, characterization of immigrant status, professional status, education, monthly income, characterization of residence, household, weight, height, co-morbidities, alcohol consumption, tobacco consumption, consumption of other substances and sexual practices, HIV status, TB symptoms, previous history of $\mathrm{TB}$, history of $\mathrm{TB}$ between contacts and treatment for TB.

\section{Data Analysis}

Descriptive statistical analysis was performed using IBM SPSS Statistics v.24 (IBM, Armonk, NY, USA). The data were described using measures of central tendency (arithmetic mean, median and mode) and dispersion (standard deviation, interval, minimum and maximum values), counts and relative frequencies according to the nature of the variables under analysis [11].

\section{Ethical Considerations}

Participation was voluntary and written informed consent was obtained from all enrolled participants. All information was handled with confidentiality. The study was approved by the Ethics Committee of Instituto de Higiene e Medicina Tropical, Universidade Nova de Lisboa (reference number 7/17).

\section{Results}

\section{Sociodemographic Characteristics}

Overall, $60 \%$ of the 100 immigrants included in this study were female, among which $8 \%$ were trans women. The average age was 33.2 years $(\mathrm{SD}=9.4)$, with the most frequent age being 25 years.

Most immigrants were from the Community of Portuguese-Speaking Countries (85.0\%), with $63.0 \%$ of these originating from Brazil (Table 1).

The majority (64.0\%) had migrated to Portugal over 1 year ago, mainly during 2017. Almost half of the participants (41.4\%) had not regularized their migratory status (Table 2). 
Table 1. Distribution of immigrants by country of origin, father and mother

\begin{tabular}{|c|c|c|c|c|c|c|}
\hline \multirow[t]{2}{*}{ Country of origin } & \multicolumn{2}{|c|}{ Immigrant } & \multicolumn{2}{|c|}{ Father } & \multicolumn{2}{|c|}{ Mother } \\
\hline & $n$ & $\%$ & $n$ & $\%$ & $n$ & $\%$ \\
\hline Brazil and South America & 66 & 66.0 & 64 & 64.0 & 64 & 64.0 \\
\hline PALOP & 22 & 22.0 & 20 & 20.0 & 21 & 21.0 \\
\hline European Union & 7 & 7.0 & 12 & 12.0 & 12 & 12.0 \\
\hline Others & 5 & 5.0 & 4 & 4.0 & 3 & 3.0 \\
\hline Total & 100 & 100.0 & 100 & 100.0 & 100 & 100.0 \\
\hline
\end{tabular}

Absolute frequency: $n$, and relative frequency: \%. PALOP, países afrícanos de língua oficial portuguesa (Angola, Cape Verde, Guinea-Bissau, Mozambique and São Tomé and Príncipe).
Table 2. Distribution of immigrants by sociodemographic characteristics

\begin{tabular}{|c|c|c|c|}
\hline & $N$ & $\%$ & Cum \% \\
\hline \multicolumn{4}{|l|}{ Gender } \\
\hline Female & 52 & 52.0 & - \\
\hline Male & 39 & 39.0 & - \\
\hline Transsexual male to female & 8 & 8.0 & - \\
\hline Non-binary & 1 & 1.0 & - \\
\hline \multicolumn{4}{|l|}{ Time living in Portugal } \\
\hline$<1$ year & 33 & 34.0 & 34.0 \\
\hline$\geq 1$ year & 64 & 66.0 & 100.0 \\
\hline \multicolumn{4}{|l|}{ Level of education } \\
\hline Incomplete secondary education & 52 & 52.5 & 52.5 \\
\hline Complete secondary education & 8 & 8.1 & 60.6 \\
\hline University education & 39 & 39.0 & 93.1 \\
\hline \multicolumn{4}{|l|}{ Monthly household income } \\
\hline$<250$ EUR & 9 & 9.2 & 9.2 \\
\hline 250-500 EUR & 8 & 8.2 & 17.3 \\
\hline 501-1,000 EUR & 40 & 40.8 & 58.2 \\
\hline 1,001-1,500 EUR & 21 & 21.4 & 79.6 \\
\hline$>1,500$ EUR & 20 & 20.4 & 100.0 \\
\hline \multicolumn{4}{|l|}{ Professional situation } \\
\hline Retired & 1 & 1.0 & - \\
\hline Student & 13 & 13.0 & - \\
\hline Student and employed & 6 & 6.0 & - \\
\hline Employed & 63 & 63.0 & - \\
\hline Unemployed & 17 & 17.0 & - \\
\hline \multicolumn{4}{|l|}{ Housing } \\
\hline Own/rented house & 69 & 69.0 & - \\
\hline family/friends' house & 15 & 15.0 & - \\
\hline Room/other & 15 & 15.0 & - \\
\hline Reception centre & 1 & 1.0 & - \\
\hline \multicolumn{4}{|l|}{ Migration situation } \\
\hline Regular & 58 & 58.6 & - \\
\hline In regularization & 22 & 19.2 & - \\
\hline Irregular & 19 & 22.2 & - \\
\hline
\end{tabular}

Absolute value: $n$, relative frequency: $\%$, and cumulative frequency: cum \%.
Most immigrants had not completed secondary education (52.5\%), 17.0\% were unemployed, and among those employed (63.0\%), 14\% performed sex work. 9.2\% of immigrants belonged to a household with a monthly income of up to 250 EUR and $8.2 \%$ lived in a household with 250-501 EUR of income per month.

$14 \%$ of immigrants were living in a room in a shared house, $15.0 \%$ were living in the home of a friend or family member, 1 claimed to live in a car and 1 in a reception centre (Table 2).

On average, the immigrants lived in a space with 3 divisions (median $=3, \mathrm{IR}=2$, $\min .=0$; $\max .=7$ ), shared with 2 more people (median $=2, \mathrm{IR}=2$, min. $=0$ and $\max$. $=12$ ).

\section{Behaviours and Practices}

Most immigrants drank alcohol (85.0\%), with 32\% doing it twice or more times a week.

Regarding tobacco consumption, $41 \%$ of immigrants smoked, with $19.0 \%$ doing it daily. The average number of cigarettes smoked per day was 7.3 ( $\mathrm{SD}=8.2$ cigarettes). Up to half of the immigrants with smoking habits smoked 4 cigarettes a day, the most frequently reported habit corresponding to smoking 1 cigarette per day $(\min .=0$; $\max$. $=40$ cigarettes $)$.

Almost half (40.0\%) of the immigrants reported the use of illicit drugs, and 1 said that he had shared injection material in the last 12 months.

About condom use during sexual intercourse, the majority $(77.4 \%)$ of the immigrants revealed that they had either never used a condom or used it only sporadically.

In addition, 9.7\% reported having had sex with an HIV-positive partner in the past 12 months, and $63.4 \%$ reported not knowing the HIV status of people with whom they had sex (Table 3). 
Table 3. Distribution of participants' behaviours and practices

\begin{tabular}{|c|c|c|c|}
\hline & $N$ & $\%$ & $\begin{array}{l}\text { Cum } \\
\%\end{array}$ \\
\hline \multicolumn{4}{|l|}{ Alcoholic beverages } \\
\hline Never & 15 & 15.0 & 15.0 \\
\hline Once a month or less & 26 & 26.0 & 41.0 \\
\hline 2-4 times a month & 27 & 27.0 & 68.0 \\
\hline 2-3 times a week & 24 & 24.0 & 92.0 \\
\hline$\geq 4$ times a week & 8 & 8.0 & 100.0 \\
\hline \multicolumn{4}{|l|}{ Number of drinks } \\
\hline $1-2$ & 48 & 57.1 & 57.1 \\
\hline $3-4$ & 19 & 22.6 & 79.8 \\
\hline $5-6$ & 8 & 9.5 & 89.3 \\
\hline $7-9$ & 5 & 6.0 & 95.2 \\
\hline$\geq 10$ & 4 & 4.8 & 100.0 \\
\hline \multicolumn{4}{|l|}{ Smoking } \\
\hline Do not smoke & 59 & 59.0 & - \\
\hline Occasionally & 22 & 22.0 & - \\
\hline Daily & 19 & 19.0 & - \\
\hline \multicolumn{4}{|c|}{ Psychoactive drugs use in the last 12 months } \\
\hline Not used & 60 & 60.0 & - \\
\hline $\begin{array}{l}\text { Consumed drugs like ecstasy, hashish } \\
\text { heroin, cocaine or amphetamines }\end{array}$ & 40 & 40.0 & - \\
\hline \multicolumn{4}{|c|}{ Frequency of condom use in the last 12 months } \\
\hline Never or sometimes & 72 & 77.4 & - \\
\hline Always used & 21 & 22.6 & - \\
\hline \multicolumn{4}{|l|}{ Sexual relations with someone HIV positive } \\
\hline Yes & 9 & 9.7 & - \\
\hline No & 25 & 26.9 & - \\
\hline Do not know & 59 & 63.4 & - \\
\hline
\end{tabular}

Absolute value: $n$, relative frequency: $\%$, and cumulative frequency: \% cum.

\section{$T B$ and/or HIV Infection}

Only 1 immigrant reported having co-infection with HIV and extra-pulmonary TB (prevalence 1\%). It was the first time this person was being treated for TB. The treatment had started 1 month before the study. In this case of co-infection, no comorbidities were identified.

Three other immigrants stated that they had been treated for TB in the past. Health professionals had told them they had TB (75 and 156 months ago; the third participant could not remember).

Regarding TB screening, 31.0\% $(n=31)$ of immigrants said that they had already done a test to know if they had the infection. On average, respondents had made a TB screening 6.3 years ago $(\mathrm{SD}=6.2)$. Half had been screened 5 years ago $(\min .=1$ and $\max .=27)$.

A significant number of respondents $(14.0 \% ; n=14)$ did not know whether they lived with people who had TB.

Tuberculosis and/or HIV Infection in Immigrants
Table 4. Characterization of immigrants regarding HIV testing and HIV status

\begin{tabular}{lll}
\hline HIV infection & $N$ & $\%$ \\
\hline Previous HIV testing & & \\
$\quad$ No & 13 & 13.1 \\
$\quad$ Yes & 86 & 86.9 \\
Serological status & & \\
$\quad$ Negative & 81 & 81.0 \\
$\quad$ Positive & 17 & 17.0 \\
$\quad$ Do not know & 2 & 2.0 \\
\hline
\end{tabular}

Absolute value: $n$, and relative frequency: $\%$.

Regarding the 5 symptoms suggestive of TB, 2 immigrants reported coughing, night sweats and severe tiredness and 2 others reported weight loss, night sweats and severe tiredness. At least 1 symptom was reported by $28 \%$ $(n=28)$ of the immigrants, 2 symptoms by 8 immigrants and 3 symptoms by 5 immigrants.

In addition to the TB symptoms referred, immigrants also reported pathologies, such as asthma $(n=7)$, chronic bronchitis, chronic obstructive disease, or emphysema $(n=4)$ and diabetes $(n=3)$.

Only 1 participant met the criteria for sputum collection, reporting at least 4 symptoms suggestive of TB. However, preliminary evaluation at the laboratory showed that the sample collected had not had enough quality to be processed.

At the time of the study, $13.1 \%(n=13)$ of immigrants had never been tested for HIV, and $86.9 \%(n=86)$ had already been tested for HIV at some point in life (Table 4). Of the $86.9 \%$ who had already been tested for HIV, $41.3 \%$ had been tested at least 1 year ago, and $19.6 \%$ had been tested in their country of origin. Among the immigrants studied, 17 were living with HIV (prevalence of 17.0\%) and all were taking antiretroviral medication. In addition, 2 more participants who were not seropositive said they were taking medication for pre-exposure prophylaxis. The rapid test was carried out on 83 immigrants, all of which tested negative for HIV.

\section{Discussion}

This study aimed at describing the distribution of TB, HIV and HIV-TB co-infection and socio-behavioural factors associated with a purposive sample of immigrants that lived in the metropolitan area of Lisbon, Portugal,

Port J Public Health 2021;39:163-169 
and that attended an NGO supporting this population. It was part of a larger research project that aimed at piloting a method of screening for TB in the immigrant population in the community, based on suggestive symptoms.

The study sample comprised 100 immigrants recruited at an NGO who answered a questionnaire on sociodemographic characteristics and health behaviours, took a rapid HIV test and provided a sputum sample if they had at least 4 out of 5 suggestive symptoms (fever, weight loss, night sweats, coughing for more than 3 weeks and severe tiredness).

Only 1 immigrant had co-infection with HIV and extrapulmonary TB. This form of TB has been commonly reported in patients with HIV. Between 1983 and 2018, 22,551 AIDS cases were cumulatively diagnosed in Portugal, of which pulmonary TB and extrapulmonary TB were the pathologies most frequently referred to as defining AIDS (25.6\% and 20.4\%, respectively) [11]. A recent study carried out in the North of Portugal revealed that extrapulmonary TB constitutes about one-third of all TB cases, with HIV co-infection and previous TB treatment increasing the risk of disseminated disease [12].

No other TB cases were identified, although 3 of the participants reported having been treated for pulmonary TB in the past, 2 being HIV positive.

The method used to decide whether to test or not for TB was likely to produce underestimation and the technique itself was not performed according to the recommended guidelines, which might influence the results. The diagnosis of TB disease relies not only on symptoms but on results from a chest X-ray and microbiological studies, which implies the collection of 3 sputum samples.

A high prevalence of HIV infection (17\%) was revealed in the immigrants studied, $16 \%$ of which originated from Africa and Latin America. This result is in line with the official data of HIV cases diagnosed in Portugal in 2020, which show that immigrants are disproportionally affected (43.1\% of cases) [11]. However, it is important to point out that the high prevalence observed can result from the fact that the NGO where immigrants have been recruited works closely with people infected with HIV.

Our study identified several behaviours that have been described as increasing the risk of HIV infection. Almost three-fourths of immigrants reported not using or rarely using condoms during sexual intercourse. More than half did not know the sexual partner's HIV status and $14 \%$ had been involved in commercial sexual activities. These findings indicate the extreme importance of comprehensive public health policies based on awareness programs for the prevention of HIV and other sexu- ally transmitted infections, easy access and consistent condom use and larger coverage of rapid testing by healthcare providers.

Being non-employed, with a low income and a lower level of education, consumption of illicit drugs and regular tobacco consumption were common characteristics in the immigrants studied, which points out social and economic disadvantages that could influence the risk of acquiring HIV and TB. A systematic literature review reported that poverty, exploitative working conditions, lack of access to health, language barriers, separation from sexual partners, housing in poorly ventilated and unhealthy spaces, ethnic and cultural issues were the main determinants for TB/HIV infection [3].

Furthermore, the fact that almost half of the immigrants did not have their migratory status regularized makes this group even more vulnerable to becoming physically and mentally ill, due to the difficulties they might face in accessing healthcare and social integration [6]. These individuals tend to have greater obstacles, often related to the scarcity of socio-economic resources, communication barriers, bureaucratic challenges in social protection services, lack of access to most healthcare and lack of knowledge of their rights that condition the fear of being reported and deported from the country $[6$, 13].

It should be emphasized that although this study has limitations related to its sampling design and descriptive nature, it included a significant number of immigrants in an irregular situation. These immigrants have often been excluded from similar studies. The information collected contributes to increasing the knowledge on the distribution of TB and HIV in immigrants living in the metropolitan region of Lisbon, as well as the socio-behavioural factors associated.

We recommend screening this population for $\mathrm{TB}$, considering the clustering of health disadvantages and the high prevalence described in official statistics. Finally, the results of this study can serve as a basis for more comprehensive studies eventually contributing to possible adjustments in health policies on latent TB infection screening and TB diagnosis aimed at culturally diverse populations.

\section{Acknowledgements}

The authors acknowledge Global Health and Tropical Medicine (GHTM) R\&D Center, Instituto de Higiene e Medicina Tropical, Universidade Nova de Lisboa for logistic and financial support, GAT - Grupo de Ativistas em Tratamento for supporting 
field work and data collection and the assistance of Jorge Ramos and Diana Machado (Mycobacteriology Laboratory, IHMT-UNL) in the preparation of the materials for samples recovery and preanalysis.

\section{Statement of Ethics}

This study was approved by the Ethics Committee of Instituto de Higiene e Medicina Tropical, Universidade Nova de Lisboa under reference number 7/17.

\section{Conflict of Interest Statement}

The authors declare that they have no conflict of interest.

\section{Funding Sources}

This study was funded by the Fundação para a Ciência e a Tecnologia - FCT, through funds to the Global Health and Tropical Medicine Research Center (GHTM - UID/04413/2020). This study was further supported by funds of the GHTM, through the project "Characterization of drug-resistant TB and HIV, and associated socio-behavioural factors among migrants in Lisbon, Portugal."

The funders had no role in study design, data collection and analysis, decision to publish, or preparation of the manuscript.

\section{Author Contributions}

R.F. conducted the data collection and analysis and wrote the paper, M.P. and I.C. revised the paper, I.F. designed the study and data collection instruments, collaborated in data analysis and wrote the paper.

\section{References}

1 Pawlowski A, Jansson M, Sköld M, Rottenberg ME, Källenius G. Tuberculosis and HIV co-infection. PLoS Pathog. 2012;8(2): e1002464.

2 World Health Organization. Global tuberculosis report 2020. Geneva: Global Tuberculosis Programme World Health Organization; 2020 [cited 2021 Mar 30]. Available from: https: //apps.who.int/iris/bitstream/hand le/10665/336069/9789240013131-eng.pdf.

3 Tavares AM, Fronteira I, Couto I, Machado $\mathrm{D}$, Viveiros $\mathrm{M}$, Abecasis $\mathrm{AB}$, et al. HIV and tuberculosis co-infection among migrants in Europe: a systematic review on the prevalence, incidence and mortality. PLoS One. 2017;12(9):e0185526.

4 Montales MT, Chaudhury A, Beebe A, Patil S, Patil N. HIV-associated TB syndemic: a growing clinical challenge worldwide. Front Public Health. 2015;3(4):e281.

5 Guthrie JL, Ronald LA, Cook VJ, Johnston J, Gardy JL. The problem with defining foreign birth as a risk factor in tuberculosis epidemiology studies. PLoS One. 2019;14(4): e0216271.
6 Deblonde J, Sasse A, Del Amo J, Burns F, Delpech V, Cowan S, et al. Restricted access to antiretroviral treatment for undocumented migrants: a bottle neck to control the HIV epidemic in the EU/EEA. BMC Public Health. 2015;15(3):e1228.

7 Carballo M, Nerukar A. Migration, refugees, and health risks. Emerg Infect Dis. 2001;7(3 Suppl):556-60.

8 Portugal Ministério da Saúde; Serviço Nacional de Saúde. Relatório anual: acesso a cuidados de saúde nos estabelecimentos SNS e entidades convencionadas 2019. Lisboa: Serviço Nacional de Saúde; 2019 [cited 2021 Mar 30]. Available from: https://www.sns.gov.pt/wpcontent/uploads/2020/09/Relatorio_Anual_ Acesso_2019.pdf.

9 Couceiro L, Santana P, Nunes C. Pulmonary tuberculosis and risk factors in Portugal: a spatial analysis. Int J Tuberc Lung Dis. 2011; 15(11):1445-54.
10 Macedo R, Antunes AF, Villar M, Portugal I. Multidrug and extensively drug-resistant tuberculosis in Lisbon and Vale do Tejo, Portugal, from 2008 to 2010. Int J Mycobacteriol. 2012;1(3):131-6.

11 Portugal Ministério da Saúde; Direção Geral de Saúde; Instituto Nacional de Saúde Doutor Ricardo Jorge. Infecção VIH e SIDA em Portugal 2020. Lisboa: Instituto Nacional de Saúde Doutor Ricardo Jorg; 2020 [cited 2021 Mar 30]. Available from: http://www.insa. min-saude.pt/relatorio-infecao-vih-e-sidaem-portugal-2020/.

12 Sanches I, Carvalho A, Duarte R. Who are the patients with extrapulmonary tuberculosis? Rev Port Pneumol. 2015;21(2):90-3.

13 Dias S, Gama A, Silva AC, Cargaleiro H, Martins MO. Barreiras no acesso e utilização dos serviços de saúde pelos imigrantes: a perspectiva dos Profissionais de Saúde. Acta Medica Port. 2011;24(4):511-6. 